\title{
Desire: The Influence of Japanese Manga
}

\author{
Julie Rees, Griffith University, Australia
}

\begin{abstract}
Within the context of art, desire as a universal condition has been investigated in many genres, including film, literature, fine art, comic books, and video games. Interestingly, there are a number of contemporary visual artists born in the seventies and early eighties resurrecting the topic of desire through the visual appropriation of Japanese manga and anime. This paper will underline how the subsequent influence of the exposure to Japanese popular cultural manga and other forms of anime during childhood have contributed to Eastern and Western contemporary art practices. The morphing of Japanese manga inspired images with Western symbolism, demonstrates the cultural mixing that artists have been exposed to in their upbringing. This investigation will formulate how the concept and appropriated visual forms of Japanese manga and anime used by relevant artists best question desire. The surrealists' believed that desire had the ability to transform new ways of seeing the world, and no doubt this impact is evident in the current works of Japanese artist Aya Takano, Chinese artist Cao Fei, and Australian artist Ghost Patrol. This study will be used to inform my own approach in expressing notions of desire in my own visual language, highlighting iconographic characters' experiences with unfulfilled desires within the narratives.
\end{abstract}

Keywords: Desire, Contemporary Art Practice, Japanese Manga, Anime

\section{Introduction}

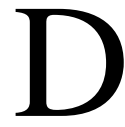

esire is a fundamental force of human existence. For the notable French psychoanalyst Jacques Lacan, who was close to Surrealist circles from the 1930s onwards...desire was something that could never be fulfilled or sated' (2001, p27). In keeping with Lacan's theory, has today's societal economic growth and constant upgrade of digital technologies contributed to individuals a dissatisfaction and dissociation from the real world, creating a need for the populace to escape from the pressures of modern day roles. Nowadays, desires are being expressed not just through the imagination but also through the construction of alternative realities via digital technologies such as mobile phones applications and internet virtual realities. Within the context of art, investigations into desire as a universal condition can be seen in many genres, including film, literature, fine art, comic books, and video games. Alternatively, the artists and intellects from the Surrealist movement also wanted to escape the pressures of their day-to-day roles resulting from World War I. Surrealist art captured the space between reality and the dream, the conscious and the subconscious. According to the Tate Museum's director, Sir Nicholas Serota (2001), "the Surrealist desire was the authentic voice of the inner self and at the same time a path to self- discovery. It was an expression...in sub-limited form, the impulse behind love but also a path to self-knowledge' (2001, p7). Art History has a long tradition of borrowing, using styles, and methods from what came before. Interestingly, there have been a number of contemporary visual artists born in the seventies and early eighties, who have visually appropriated Japanese manga and anime in order to express their desires to escape the 'real world' by creating alternative realities in their work. The definition of desire in this instance refers to modifying an existing narrative of the self, by bridging the gap between reality and fantasy.

First, the birth of Japanese manga was to give the people of Japan cheap entertainment, an aid to temporarily escape from the harsh realities of life experienced after World War II. Referencing this impoverishment, researcher Frederik Schodt states "Manga played a major role in... shaping the feelings and attitudes of children and young adults" (1997, p10) playing a key role in the development of youth popular culture within a global context. This is in keeping with postmodernist art practices which, according to art historian Scheider, "it involves the 'appropriation' of ideas, symbols, artifacts, image, sound, objects, forms, or styles from other

The International Journal of Critical Cultural Studies

Volume 10, 2013, www.thehumanities.com, ISSN: 2327-0055

(C) Common Ground, Julie Rees, All Rights Reserved

Permissions: cg-support@commongroundpublishing.com 
cultures, from art history and from popular culture” (2003, p215). Researcher Craig Norris argues "the manga and anime influence and brand recognition has helped open up a global market for manga-style artwork" (2009, p254). This paper will underline how the subsequent influence of the exposure to Japanese popular cultural manga and other forms of anime during childhood have contributed to Eastern and Western contemporary art practices. The morphing of Japanese manga inspired images with Western symbolism demonstrates the cultural mixing that artists have been exposed to in their upbringing. The surrealists' believed that desire had the ability to transform new ways of seeing the world, and no doubt this impact is evident in the current works of Japanese artist Aya Takano, Chinese artist Cao Fei and Australian artist Ghost Patrol. This study will be used to inform my own approach in expressing notions of desire in my visual language, highlighting iconographic characters' experiences with unfulfilled desires.

\section{Desire and the Influence of Japanese Manga and Anime}

Appropriating Japanese manga and anime has allowed young international contemporary artists to reinterpret this visual medium by constructing alternative realities, blurring the lines between realities and fantasy. Since the late 1990s, this stylistic direction is effective in its abilities to capture notions of dreams, desires, and a type of surrealistic hyper-reality, perfect to feature aspects of desire in all its forms.

In her essay 'Toward Eternity', author Akikio Miki notes “manga artists of the 1970s, who established escapist environments and created their own sanctuaries, created networks of salvation to rescue teenage girls from the 'gravity' of social constraints and questions of self-existence. The exposure to manga has conceptually inspired Aya Takano's art practice in terms of image making. Takano continues to explore notions of desire in her work by inserting daydream-like landscapes into her paintings of the modern city of Tokyo, she manages to perceive the ordinary through a different lens, and proposes the development of the imagination as a means of release from ordinary life" (2002, p6). Despite being inspired by science fiction and comic books, Takano's wild imagination is demonstrated through the manifested worlds in her paintings. To her, they seem utterly real, and she hopes that they will help her audience transcend the day-to-day repetition of their lives, to resist the trappings of conventional morality. The persistence of the same figure in Takano's work creates a serial format and provides for a thorough exploration of multiple themes ranging from personal experiences to social commentary. As described by art journalist, Lilly Wei, "her colours are muted primaries with a gentle glow, and the surface flickers with feathered strokes that recall pencil marks as light as thistledown” (Wei 2007, p18). The undertone of youthful sexuality becomes somewhat disturbing and is evident in her work, Yoshino Cherry (2009) (see fig.1). There are many works, where her characters are kissing and fondling each other while surrounded by complicit animals. Their eroticism is shot through with a kind of wonder and/or bewilderment: as they seem to be astonished to have found themselves experiencing such intimacy and strange sensual contact. This is also evident in her work She saw the liquid through the thin rubber (2007) (see fig. 2), as her characters respond inappropriately to the social context. In this work, it displays a naivety in sexual experiences, in the forefront of the image the character is observing what appears to be a used condom, exemplifying the character's inexperience within the narrative.

Perhaps the reasoning behind Takano's work is the desire to escape traditional social expectations and, in this case, sexual taboo. By attempting to break away from the strict traditional social codes of her heritage, she uses references of 'desire' in her paintings to reveal the happenings behind closed doors. Takano's work, in pictographic terms, merges science fiction with personal experience. She inherently questions youth identity and addresses desire through sensual experimentation. Takano executes her images with gouache and acrylic paint techniques, depicting youthful tales in imagined worlds. 
Since the 2000's, visual narratives are embracing the digital age, both Eastern and Western contemporary art practitioners have incorporated a combination of inspired Japanese aesthetics with media technology in their work allowing a panorama of contemporary art contexts to emerge. Chinese artist Cao Fei is an artist who draws on network technologies and her surroundings to create her imagined worlds. In contrast, Takano uses traditional art materials of gouache and acrylic paint. The infinite possibilities of the web define alternative realities where anonymity is welcomed and potentially can be psychologically rewarding. Scholars agree that the rapid growth of these alternative realities is beneficial as the ambiguity of social network profiles allows people to create an identity and find social acceptability without having to directly-face scrutiny. The World Wide Web is altering human social interaction and the way the brain processes information. According to arts writer Matt Locke, "it has created a utopia of instant, unmediated connectivity across distance and time, allowing users to route around physical and social barriers, creating a flexible exchange of messages that suits both sender and receiver” (Locke, p159, 2002). He also notes "users...'adopt technologies that closely match their behaviour and desires" (Locke, p162 2002). Arguably, social media has created a new way in which people 'desire' individuals and objects in the $21^{\text {st }}$ century. In psychological terms, it suggests the social significance of this new media and could explain why local and international artists would use it in their practice.

Fei’s film 'i. Mirror '(2007) (see fig.3) uses networking site called 'Second Life' as her platform to document the wanderings and interactions of her second life avatar, China Tracy. 'Second Life' is a free three-dimensional virtual world where users can socialise, connect, and create using free voice and text chat. Fei immerses herself in the act of role-playing with another Second Life character named Hug Yue, a Californian communist bank robber. The artist simultaneously portrays herself as actor in, a subject of, and the editor of the film conceived as a documentary but produced entirely in animation. Again, we see a juxtaposition of the real and the unreal. Justin Clemens, an art writer, postulates "the film mimics a kind of sentimental generic chick-flick, in which boy meets girls in various romantic fantasy situations” (2009, p12). They find themselves alone together in an urban train-carriage; in a hot air balloon; and in bars where they seem to exchange meaningful yet illogical statements by text ; or they play pianos or guitars with a Hollywood-style cross cutting and a sentimental soundtrack that's intended to jerk tears. Journalist Wagner James interviews Fei and she states,

'For me, Second Life is a new world, but it's still surrounded by an old world system, it parallels and mirrors our 'Real Life'. They are not what they originally are, and yet they remain unchanged. Second Life is artificial and digital landscape, but human nature is behind it, you can see how real the people are. Whereas on the reality's end of this combined ultra-space, there is still love for simplicity and the pursuit of freedom, creativity, and imagination, and only these possibilities made me treasure this Second Life world.'

In 'i. Mirror' (2007), a New Zealand art critic Hamish Grieves argues "her conclusion is that 'every world is an abyss' as it structures a real life/Second Life consequence: being enveloped within Second Life mirrors our complicity but also our agency with contemporary consumer society" (2009, p8). Fei's idea of utopia enables her to construct 'a new kind of fairytale- like world', although heavily based on reality and cyber space avatars, Takano uses self-created characters anchored in a more fantasy based scenarios. Both Takano and Fei share a paradox between rationality and absurdity in their work.

An additional artist who also creates a paradox between rationality and absurdity in their work is Australian artist Ghostpatrol. In his work, Sights (2009) (see fig.4), a single character appears to be flying on a rhinoceros' back (the character's means of transport) and as the title suggests, sightseeing in a fantastical fashion. Child-like nostalgia and a sense of anticipated adventures 
feature in his work. His work mimics a surreal-like setting, possessing a sense of wonder and excitement through the characters' experiences. This work is significant in this new visual genre as it captures the notion of desire through escapism by appropriating Japanese manga and anime in his work. The influence of Japanese manga is very much a part of Australian popular culture as it is globally. With TV series such as Astro Boy, Dragon Ballz, and Pokémon, there is no doubt where Ghostpatrol drew his inspiration from.

Krystyn Gorton postulates "it is desire's abstract nature ....that draws us in and invites us to make sense of its energy' (Gorton 2008, p1) and even though all three artists use different methods to express the notions of desire, their characters 'desire to escape reality' is more exaggerated than in real life. It questions the gap between reality and fantasy signifying the necessity to escape from built up pressures of daily life much the like the Surrealist artists did in their time. The appropriation of this powerful medium has provided contemporary art practitioners to reinterpret this visual style within a global context this is done by combining their own heritage and narrative with distinctive Japanese aesthetics.

This study has informed my own art practice as the influence of Japanese manga and anime is a key element in my work. Through appropriation and using varied studio methodologies, my work relies on concepts of transformation from reality to illusion and back (see fig.5) (2012). The notion of desire articulated through fantasy and it is essentially what my studio project encompasses; it constructs desired realities through the aesthetic creation of a new visual dialogue.

\section{Conclusion}

Appropriating Japanese manga and anime has given contemporary artists an avenue to express desire though fantasy. The artists' work discussed in this paper also reflects the times where societies need an escape from modern-day roles with evidence suggesting technological and economic growth are the reason behind this need. Artists are exploring alternative realities as a means to relieve built-up pressures from daily life. 


\section{REFERENCES}

Albertini, C 2008, Avatars, and Antiheros: A guide to contemporary Chinese Artists, Kodansha International, Tokyo.

Alonzo, P 2008, The Upset: Young Contemporary Art, Gestalten, Hong Kong.

Bach, H 2007, "Composing a Visual Narrative” in D. Clandinin (ed.) Handbook of Narrative Inquiry: Mapping a Methodology, Sage, California, pp280-307.

Bach, H 2007, Handbook of Narrative Inquiry: Mapping a Methodology, Sage, California.

Baddeley, J \& Jefferson, A 2007, “Charting the Life Story’s Path” in J. Clandinin (ed.), Handbook of Narrative Inquiry: Mapping a Methodology, Sage, California, pp.177-207.

Bataille, G 1994, The Absence of Myth, Verso, London.

Berger, A 1997, Narratives in Popular Culture, Media, and Everyday Life, Sage, California.

Boucher, G 2005, Traversing the Fantasy: Critical responses to Slavoj Zizek, Ashgate, London.

Bradley F2002, Paula Rego, Tate, London.

Bryce, M \& Davis, J 2006, Manga/Anime, media mix: scholarship in a post-modern, global Community, Macquarie, Sydney.

Chadwick, C 1971, Symbolism, Methuen \& Co, London.

Clandinin, D, Connelly, F 2000, Narrative Inquiry: Experience and Story in Qualitative Research, Jossey-Bass, San Francisco.

Coats, K 2004, Looking Glasses and Neverlands: Lacan, Desire, and subjectivity in Children's Literature, Lowa, California.

Deignan, A 1997, Metaphors of Desire, in K Harvey \& C Shalom (eds), Language and Desire: Encoding Sex, Romance and Intimacy, Routledge, New York.

Denis, J 1990, The Matrix of Narrative: Family System and the Semiotics of Story, Mouton de Gruyter, Berlin.

Dewey, J 1934, Art as Experience, Perigee Books, New York.

Duplessis, Y, 1978, Surrealism, Greenwood Press, Connecticut.

Elkind, D 1967, Egocentrism in Adolescence: Child Development, no38, pp1025-1034.

Elkind, D 1998, All Grown Up and No Place to Go, Perseus Book, New York.

Erikson, E 1963, Childhood and Society, W.W. Norton, New York.

Erikson, E 1968, Identity: Youth and Crisis, W.W. Norton, New York.

Finkelstein, H 1979, Surrealism, and the Crisis of the Object, University Microfilms International, Michigan.

Forte, G and Miller, P 2008, Desire of the Analysts: Psychoanalysis and Cultural Criticism, State University of New York, New York.

Federico, C 2008, Chinese Art Rises Again, Aesthetica, Vol. 8 no.3, pp 34-37.

Fleming, J \& Murakami, T 2001, My Reality: Contemporary Art and the Culture of Japanese Animation, Independent Curators International, New York.

Gorton, K 2008, Theorising Desire: From Freud to Feminism to Film, Palgrave Macmillan, New York.

Grant, B 2007, Film Genre: From Iconography to Ideology, Wallflower Press, London.

Grieves, H 2009, Cao Fei Utopia, Institute of Modern Art, South Brisbane.

Habermas, T \& Bluck, S 2000, Getting a Life: The Emergence of the life story in adolescence, Psychological Bulletin, no 126, pp748-769.

Holland, S 2009, Sci-Fi Art, Harper Collins Publishers, New York.

Hook, R 1979, Fantasy and Symbol, Academic Press, Canberra.

Hourihan, M 1997, Deconstructing the Hero: Literary theory and children's literature, Routledge, New York. 
Imamura, A 2009, "Family Culture” in Y. Sugimoto (ed.), The Cambridge Companion to Modern Japanese Culture, Cambridge, Melbourne, pp 76-91.

Irvine, W 2006, On Desire, Oxford University Press, New York.

Jagodzinski, J 2004, Youth Fantasies: the Perverse Landscape of the Media, Palgrave Macmillian, New York.

Leitch, T 1986, What Stories Are: Narrative Theory and Interpretation, Pennsylvania State University, London.

Levi, A 1996, Samurai from outer space: understanding Japanese animation, Open Court, Chicago.

Lunning, F 2006, Mechademia: Emerging Worlds of Anime and Manga, University of Minnesota Press, London.

Lunning, F 2006, Mechademia: Network of Desire, University of Minnesota Press, London.

MacWilliams, M 2008, Japanese Visual Culture: Explorations in the world of Manga and Anime, M.E. Sharpe, New York.

McAdams, D 1987, “A Life-Story Model of Identity” in R Hogan \& W Jones (eds), Perspectives in Personality, JAI Press, Greenwich, vol. 2, pp.15-50.

McAdams, D 1997, The Stories we Live By: personal myths and the making of the self, Guilford Press, new York.

de Meredieu, F 2005, Digital and Video Art, Chambers Harrap Publishers, Edinburgh.

Mitchell, W 1981, On Narrative, University of Chicago Press, Chicago.

Mundy, J 2001, Surrealism: Desire Unbound, Princeton University Press, Paris.

Museum of Contemporary Art, San Diego 1997, Blurring the Boundaries: Installation Art 19691996, Marquand Books, Hong Kong.

Murakami, T 2005, Little Boy: the arts of Japan's exploding subculture, Yale University Press, New York.

Murakami, T 2000, Superflat, Madra Publishing, Tokyo.

Nalven, J 2005, Going Digital: The practice and vision of digital artists, Thomas Course Technology, New York.

Napier, S 2005, Anime: from Akira to Howl's Moving Castle, Palgrave Macmillian, New York.

Napier, S 1998, "Four Faces of the Young Female” in D.P Martinez (ed), The Worlds of Japanese Popular Culture: Gender, Shifting Boundaries and Global Cultures, Cambridge, Beijing, pp91-109.

Noble, A 1992, Outer Space, South Bank Centre, Newcastle.

Noe, C, Piech, X \& Steiner, C 2008, Young Chinese Artists: The Next Generation, Prestel, Munich.

Norris, C 2009, "Manga, anime and visual art culture” in Y. Sugimoto (ed.), The Cambridge Companion to Modern Japanese Culture, Cambridge, Melbourne, pp 236-260.

Read, H 1978, Surrealism, Scholarly Press, Michigan.

Rush, M 2005, New Media in Art, Thames \& Hudson, London.

Sartre, J 1989, Being and nothingness: an essay on phenomenological ontology, Routledge, London.

Schiff, G 1978, Images of Horror and Fantasy, Harry N. Abrams, Tokyo.

Scheider, A 2003, An Appropriation: A critical re appraisal of the concept and its application in global art practices, Cambridge, New York.

Schodt, F 1983, Manga Manga! The world of Japanese Comics, Kodanasha, New York.

Schor, J 2004, Born to Buy: the commercialised child and the new consumer, Scribner, New York. Short, R 1980, Dada \& Surrealism, Octopus Books, London.

Smith, K 2007, The Real Thing: contemporary art from China, Tate Liverpool, viewed 19 June 2010, http://www.saatchi-gallery.co.uk/blogon/art_news/karen_smith_on_the_Real _Thing/.

Sugimoto, S Ed 2009, Modern Japanese Culture, Cambridge University Press, Beijing. 
Telotte, J.P 1995, Replications: a robotic history of the science fiction film, University of Illinois Press, New York.

Toku, M 2001, What is Manga: The Influence of Pop Culture in Adolescent Art, Art Education, March pp 11-17.

Van Pelt, T 2000, The Otherside of Desire: Lacan's Theory of the Registers, New York Press, New York.

Vartanian, I 2005, Drop Dead Cute, Chronicle Books, Tokyo.

Waldberg, P 1978, Surrealism, McGraw-Hill Book Company, Berlin.

Wands, B 2006, Art of the Digital Age, Thames \& Hudson, Berlin.

Warner, M 1996, The Inner Eye: Art Beyond the Visible, Cornerhouse Publishers, Manchester.

Wei, L 2007, Aya Takano, Art in America, Vol.7 no. 318, pp 18-19.

Yomota, I 1994, Manga Genron, Chikuma Shobo, Tokyo.

Zupancic, A 2000, Ethics of the Real, Verso, New York 


\section{APPENDIX:}

\section{List of Images}

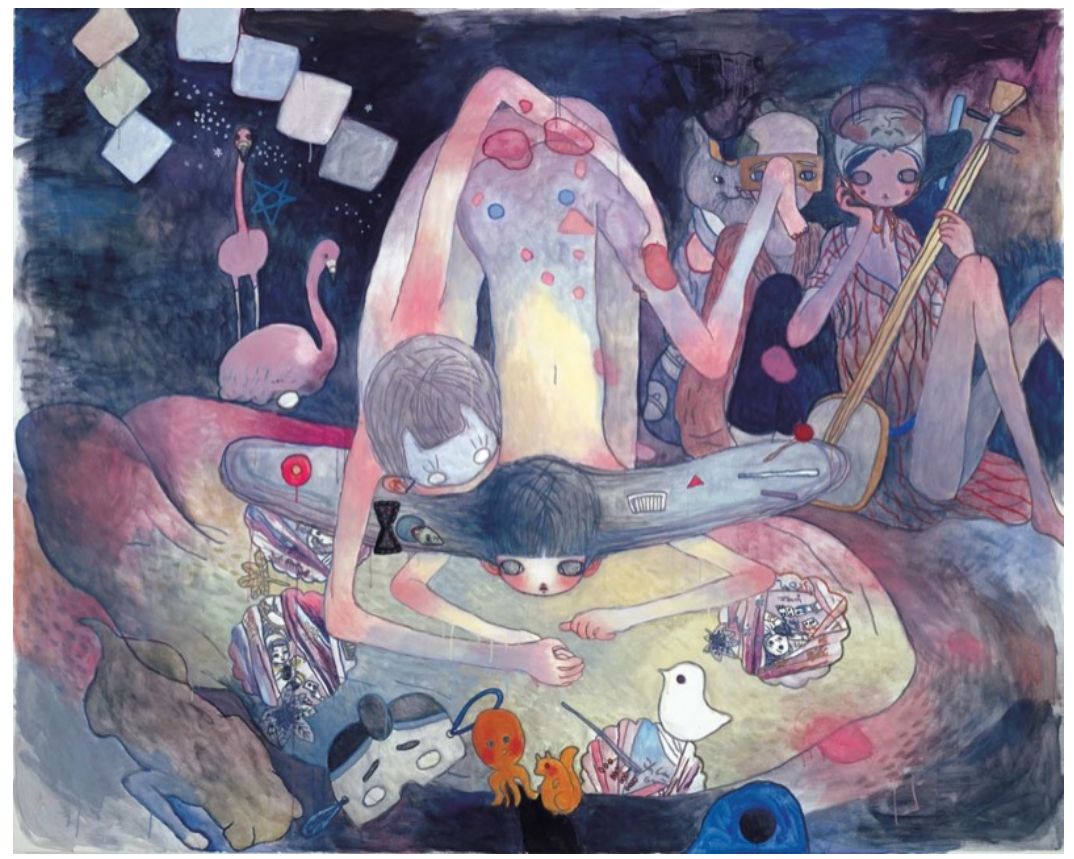

Figure 1: Aya Takano, Yoshino Cherry, 2009, Acrylic on Canvas, 181.8 x 227.3cm (Galerie Perrotin, n.d, image, viewed, 16 April 2012) 


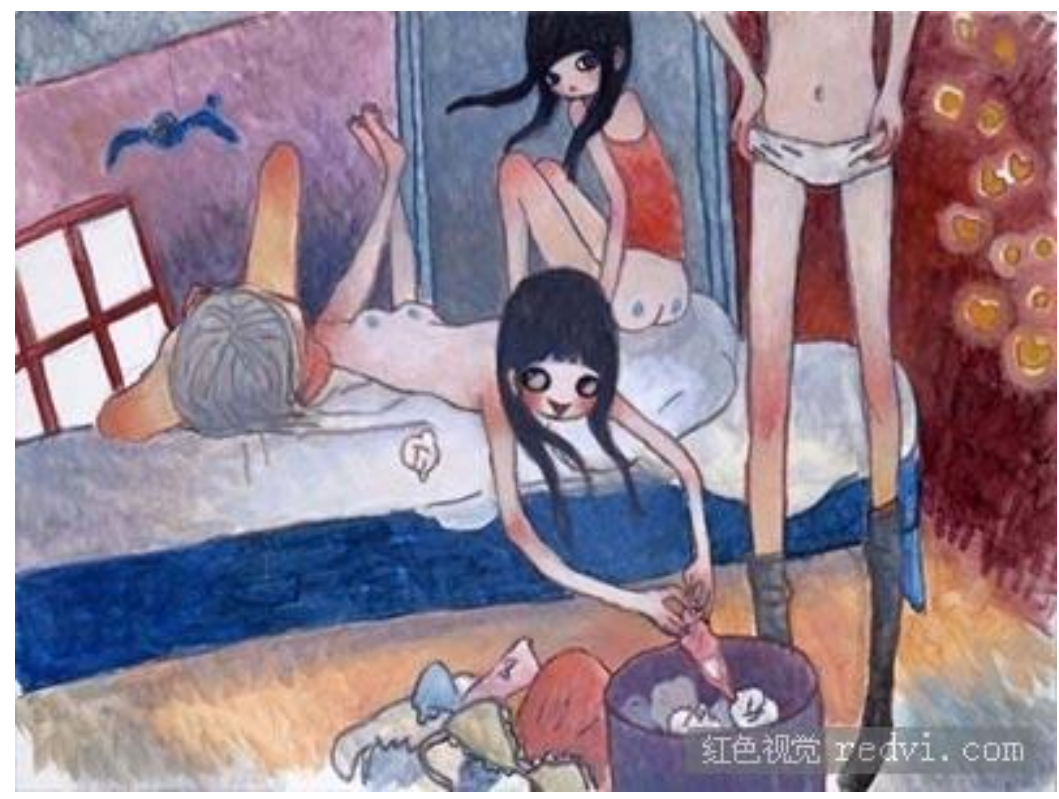

Figure 2: Aya Takano, She Saw the Liquid through the Thin Rubber, 2007, Acrylic on Canvas, 193.9 x 259.1 x 3.7cm (Galerie Perrotin, n.d, image, viewed, 16 April 2012)

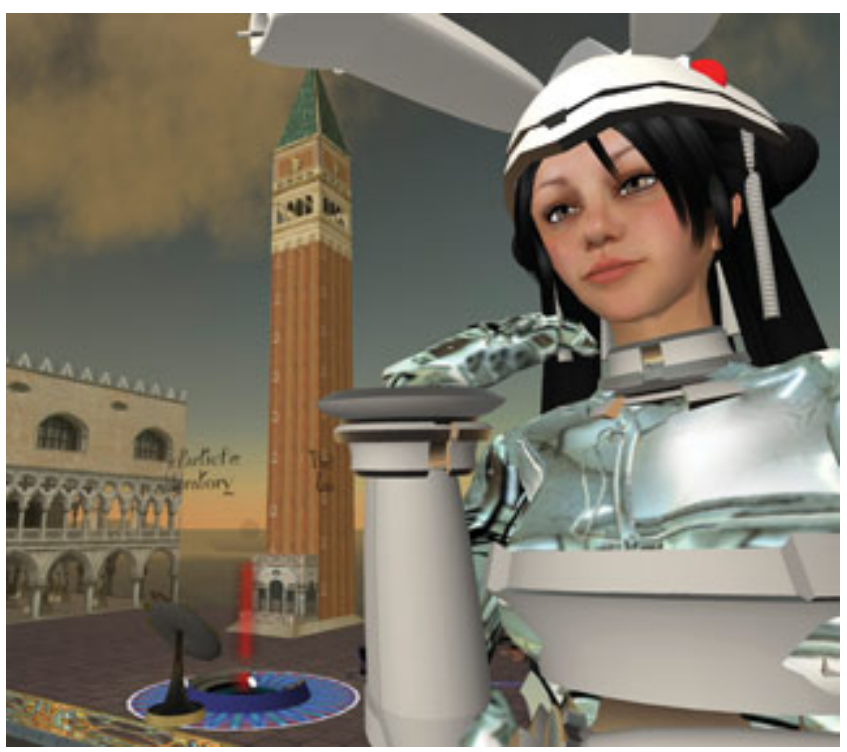

Figure 3: Cao Fei, i.Mirror, 2007, three-part machinima of the second life experience, (http://nwn.blogs.com/nwn/2007/07/this-is-truly-c.html, n.d, image, viewed, 16 April 2012) 


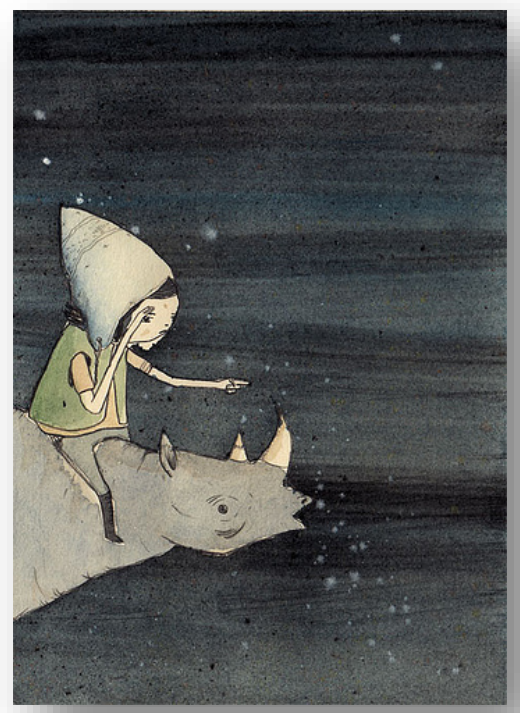

Figure 4: Ghostpatrol, Sights, 2009, pencil and watercolour on paper, 13cm x 18cm (Flicker, n.d, image, <http://www.flickr.com/photos/ghostpatrol/4099348338/>).

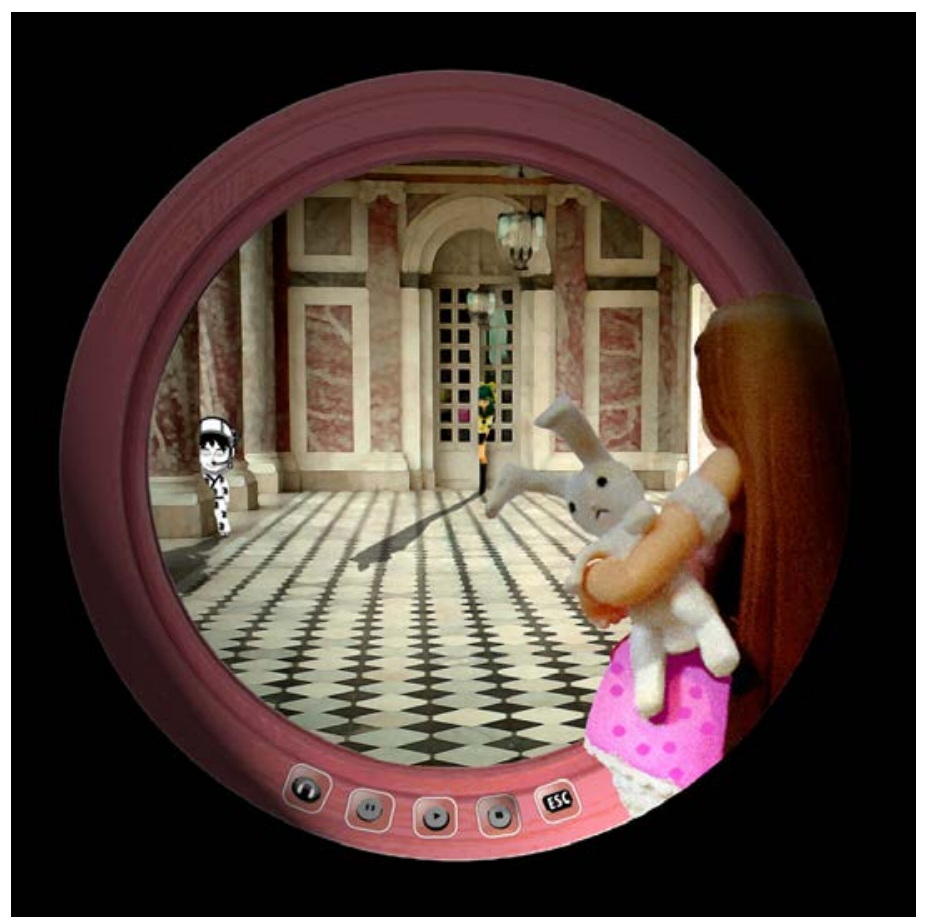

Figure 5: Julie Rees, At Versailles, 2012, pen, grapite, and digital imagery, 80 x $80 \mathrm{~cm}$ 


\section{ABOUT THE AUTHOR}

Julie Rees: Currently, my research is investigating desire through visual interpretations in contemporary art, specifically focusing on artists who are influenced by Japanese manga and anime aesthetics. This will in turn, inform my own studio art practice to be able to effectively communicate the complexity and interactivity of mixed media in today's techno-driven contemporary society. 